\title{
The Expected Role of Librarian 2.0 in the Library 2.0 Era
}

\author{
도서관 2.0 시대의 사서 2.0 에게 기대되는 역할에 관한 연구
}

\author{
Sue Yeon Syn* \\ Sung-Min Kim**
}

\begin{abstract}
The idea of Library 2.0 originated from the concept of Web 2.0 social interactions within the Web. From this aspect, Library 2.0 is a library blended with Web 2.0. The most remarkable features of Library 2.0 are interactions and user involvement. Users' roles in new library environments are greater since they can contribute to establishing a library collection by annotating, blogging, reviewing, etc. While users' roles become important, the responsibilities of the librarians increase due to the unfiltered information created by users. Librarians now should extend their roles as information creators, organizers, providers, managers, as well as moderators. In this paper, we reviewed the current literature on the new paradigm of digital libraries, Library 2.0, and the development of Library 2.0. In addition, we discuss the extended role of the Librarian 2.0 in Library 2.0.
\end{abstract}

\section{초 록}

도서관 2.0 개념은 웹상에서 상호작용하는 웹 2.0 의 개념에서 비롯되었다. 이런 측면에서 볼 때, 도서관 2.0 은 웹 2.0 의 조합이고 가장 주목할만한 특징은 상호작용과 이용자 참여라 할 수 있다. 변화된 도서관 환경에서의 이용자 역할의 비중은 도서관 소장자료에 대한 그들의 태깅, 블로깅, 서평 등과 같은 기여로 점점 더 커져왔다. 이렇듯 이용자의 역할이 변화하면서 도서관 사서들의 책임 또한 이용자들이 만들어낸 정제되지 않은 정보원의 점검자 역할에까지 이르게 되었으며, 결국 정보의 생산자, 조직가, 제공자, 관리자 뿐만 아니라 조정자의 역할로 확장되게 된다. 본 연구에서는 디지털 도서관의 새로운 패러다임으로 인식되는 도서관 2.0 과 그 발전에 대한 최근의 연구들을 살펴보고 도서관 2.0 측면에서의 사서의 확대된 역할로서 사서 2.0 에 대해 논하였다.

Keywords: library 2.0, librarian 2.0, digital libraries, user involvement, web 2.0 도서관 2.0 , 사서 2.0 , 디지털 도서관, 이용자 참여, 웹 2.0

* University of Pittsburgh, School of Information Sciences, Pittsburgh, PA, USA. (sus16@pitt.edu)

** University of Pittsburgh, School of Information Sciences, Pittsburgh, PA, USA. (suk30@pitt.edu)

- Received : 27 May 2010 - Revised : 4 June 2010 - Accepted : 15 June 2010

- Journal of the Korean Society for Information Management, 27(2): 201-216, 2010. [DOI: 10.3743/KOSIM.2010.27.2.201] 


\section{Introduction}

Since the term "digital library" emerged, the environment of digital libraries has changed dramatically. In the initial stage of digital libraries, the main concern was how to deal with searching catalogs and finding relevant keywords. As search engine techniques and metadata schemes evolve, database and cataloging systems let users to find information in more convenient ways. Despite the fact that library patrons are often very satisfied with reference services in the library building (Kuchi et al. 2004), they still prefer web searching for finding information due to several reasons, such as location, time, and convenience. Recent web services adopted the concept of the "Web 2.0" and provide users with interactive services, such as social networking.

Along with the development of Web 2.0 technology, the technologies available for digital libraries have evolved, as well as the model of the digital library. The current prevailing web applications serve users with up-to-date technology such as a central access point, social interaction, device-free accessibility, and personalized services. Similar to web applications, users expect digital libraries to provide services that enhance information usability, accessibility, and sharing. Renda and Straccia (2005) pointed out that users often search for the same information in a digital library but have no means of sharing their customized information with other users, even though other services available on the Web provide personalized pages for users to store, share, annotate, or customize such information. They emphasized that information sharing is not only a digital library's main goal but the Web's, as well. They suggested that the library's interface should shift from passive mode to proactive mode in offering and tailoring information for individual users. Other researchers such as Kantor (1993), King (1994), and Koenig (1990) agreed that users should have a chance to contribute to the library collection's development through user-supplied data. However, digital libraries are still struggling to promote interaction between users and the library system, including librarians. Within general library systems, users are only allowed to search information with little ability of adding related information or annotations, whereas current Web 2.0 systems let users play active roles as information providers.

Researchers have made efforts to develop webbased services for digital libraries by applying various technologies to improve support for their online patrons. By means of communication, people can cooperate with others and do social activities within network communities. Such services can be expanded by adopting the product of users' collective effort. The Web is still continuously growing, and the contents of the community of digital libraries will represent an increasingly smaller portion of the total number of worthwhile Internet resources (Mason et al. 2000). Thus, it is considered that the social interaction among users would enrich the accessibility of information on the Web.

Digital libraries face many challenges and needs to prepare its new features in order to sustain its role as a center of information and education. In 
this paper, based on the observation and review of current Web 2.0 and Library 2.0 literature, we will discuss the changing expectations of digital libraries and related challenges that digital libraries face. In addition, the changing roles of librarians and users in digital libraries due to technical improvements will be discussed. The significance of understanding the shift in Librarian 2.0's roles in Library 2.0 has not been explored yet. Since user participation may cause confusion in retrieving and organizing information and mislead other users as they use the library and its collections, it is necessary to know the impact of the roles of Librarian 2.0. In this paper, we will discuss the transition of the major characteristics of Librarian 2.0's roles, and it is expected that the discussion will provide the future directions for digital libraries as Library 2.0, and more importantly, the path to take for Librarian 2.0.

\section{Trends of Digital Libraries: the Past and the Current}

\subsection{Traditional Digital Libraries}

The development of technology and the Web forced the reconstruction of the library's services, functions, and structures. In the 1990s, the digital library was viewed as a new type of library in which users access information in digital formats by using networks. Gapen $(1993,1)$ defined the digital library as,

\begin{abstract}
"of remote access to the contents and services of libraries and other information sources, combining an on-site collection of current and heavily used materials in both print and electronic form, with an electronic network which provides access to, and delivery from, external worldwide library and commercial information and knowledge sources."
\end{abstract}

As described in the definition, the main concept of the digital library would be interoperating library networks that connect resources among the libraries and provide information to their users. The Digital Library Federation (1998) also defined the term digital libraries as,

"organizations that provide the resources, including the specialized staff, to select, structure, offer intellectual access to, interpret, distribute, preserve the integrity of, and ensure the persistence over time of collections of digital works so that they are readily and economically available for use by a defined community or set of communities."

This definition emphasizes the role of digital libraries as the collection of information and an economical access to it. It can be realized that the major role of digital libraries is defined as information providers.

In the early stages of digital library development, the main concerns were how to deal with digitizing existing sources, creating large-scale collections, 


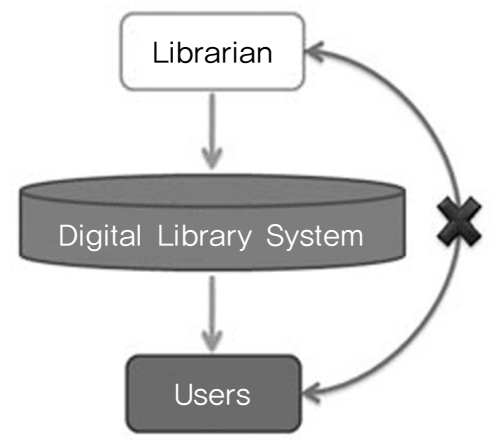

〈Figure 1> Conceptual Model for Traditional Digital Library

finding technological solutions, and providing simple forms of access. Therefore, the major functionality of the digital library was made possible from the librarian's input during the collection development process. Figure 1 represents a conceptual model of the digital library in terms of the information flow made by librarians and users. Librarians provide digital resources - a collection of digitized resources and/or web resources - to the digital system. The digital system stores the collection and presents its contents to users in various ways, e.g. browsing and searching. Users, through their own effort, try to find necessary resources from within the provided collection - there is no direct way for users to interact and communicate with librarians in real-time. Reference services are provided in either a one-way communication in format, such as prepared instructions or FAQ, or two-way communication that lacks immediacy, such as exchanging email messages.

Levy and Marshall (1995) observed that digital library users' information seeking behavior is more collaborative than generally realized. They search information by communicating with other members, and they look not only for materials and specific answers, but for solid evidence, new interpretations, and new methods of finding information. Users' expectations for dealing with information have grown, and they sometimes want to participate in creating and distributing contents. The expected changes for the digital library environment became possible with the emergence of Web 2.0 technologies. It is required for the librarians to understand users' needs in the digital environment and play new roles for their users to communicate, socialize, and cooperate with one another.

\subsection{Library 2.0}

Traditionally, librarians have carefully selected and organized resources for digital libraries. In digital libraries, librarians have the great opportunity to provide direction and assistance to avoid information overload for their patrons. The digital library enables patrons to access the library and use networked resources and services anytime and from any place where an Internet connection and computing equipment are available (Johnson et al. 2004). By adopting the Web 2.0 model in the traditional digital library, a new concept of digital library, Library 2.0, has emerged. In 2005, Michael Casey coined the term "Library 2.0" in his blog, extending the idea of Web 2.0 to libraries. Casey and Savastinuk (2006) defined Library 2.0 as,

"[i]t is a model for library service that encourages constant and purposeful change, inviting user 
participation in the creation of both the physical and the virtual services they want, supported by consistently evaluating services. It also attempts to reach new users and better serve current ones through improved customer-driven offerings. Each component by itself is a step toward better serving our users; however, it is through the combined implementation of all of these that we can reach Library 2.0."

Compared to the definitions of digital library by the Digital Library Federation (1998) and Gapen (1993), it is clear that the users' role as library contributors has been much improved in Library 2.0. Casey and Savastinuk's definition emphasized the changes in users' role in Library 2.0; however, it did not provide any possible changes in directions and roles for librarians.

Many researchers have examined applying Web 2.0 to digital libraries from different perspectives and tried to suggest how to increase patronage in terms of socializing, sharing, and collaborating in the library community (Abram 2006; Maness 2006; Casey and Savastinuk 2006; Courtney 2007). Considering the characteristics of Web 2.0 applications, the major functionality suggested is to create space where user may add annotations and comments on certain information for user satisfaction in the digital library system.

Biancu (2006) introduces the Library 2.0 Memo Map to understand the principles and important aspects of Library 2.0. The focus from the Library 2.0 Memo Map can be summarized into four essential elements that Maness (2006) explains as the theory for Library 2.0: 1) It is user-centered; 2) It provides a multi-media experience; 3) It is socially rich; and 4) It is communally innovative. Similar to the features of Web2.0, Library 2.0 facilitates a user-based information sharing environment within virtual community conditions (Stephens and Collins 2007). Figure 2 represents the early conceptual model of Library 2.0 in terms of the activity made by librarians and users. While Librarians in the Library 2.0 model may act as facilitators and provide the support role, they are not necessarily primarily responsible for the creation of the content. Unlike in the traditional digital library model (Figure 1), users are able to input information to the library system. They find necessary resources from other information sources and input them into the system. They also annotate or rate existing resources in the library's collection. The library patron's role as resource creator has increased, and they interact with other patrons, as well as librarians.

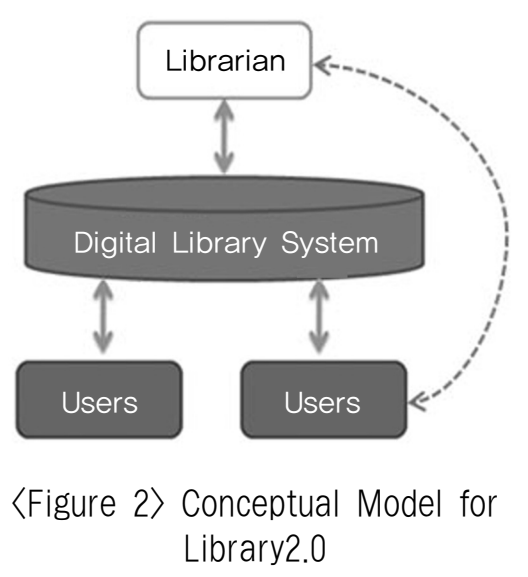


2.2.1 Web 2.0 Components for Library 2.0

The term, Web 2.0, was first introduced by Tim O'Reilly which then was promoted at O'Reilly's Web 2.0 conference in 2004 (Black 2007). In the O'Reilly blog (O’Reilly Radar 2005), he defined Web 2.0 as,

"the network as platform, spanning all connected devices; Web 2.0 applications are those that make the most of the intrinsic advantages of that platform: delivering software as a continually-updated service that gets better the more people use it, consuming and remixing data from multiple sources, including individual users, while providing their own data and services in a form that allows remixing by others, creating network effects through an 'architecture of participation,' and going beyond the page metaphor of Web 1.0 to deliver rich user experiences."

As explicitly stated in O'Reilly's definition as "architecture of participation," Web 2.0 is ultimately about a social phenomenon which is not only social network experiences, but creating and distributing content. Web 1.0 represents one-way broadcast strictly separating the information creators and consumers, whereas Web 2.0 represents two-way communication methods focusing more on human interaction and participation (Abram 2006; Habib 2006). A major change in Web 2.0 is that users contribute to their community by creating and distributing content, and therefore communicate within the Web through various methods. The most widely-used methods of Web 2.0 applications include blogs, wikis, tagging, mash- ups, podcasting, and RSS feeds (Maness 2006; Anderson 2007; Stephen and Collins. 2007). By adopting several components of Web 2.0 applications, digital libraries will improve the users' experience and role in collaboration, social networking, and information sharing in the library.

\section{- Blogs and RSS Feeds}

A blog is a web-based publication tool that allows users to create and publish content. It refers to a webpage, called a "post", consisting of brief paragraphs of users' thoughts, useful information, personal diaries, or links arranged in the style of an online journal (Anderson 2007). RSS (Really Simple Syndication) feeds, previously known as Rich Site Summary, are XML-based resource descriptions of content from a blog or other source, providing users with a way to syndicate and republish content on the Web. Whenever the source gets updated, the RSS feed also gets updated and any aggregators that subscribe to the feed are notified (Stephen and Collins 2007). The RSS feeds's major contribution is to provide a shortcut method for a webpage to request updates without requiring users to visit multiple websites all the time (Anderson 2007). Currently many libraries are using blogs as a channel to provide news and to keep in touch with their users. For example, Kansas State University libraries actively post library news to blogs categorized in several topics for their patrons. Patrons can also be immediately notified of library news updates by subscribing to their RSS feeds. 
- Wikis

A wiki is essentially a set of open, collaborative web pages enabling user groups to add, modify, and delete contents (Maness 2006). Users develop a wiki collaboratively for several purposes, such as group projects, knowledge bases, or resource repositories. The popular success of Wikipedia has proved that the concept of the wiki, as a collaborative tool that facilitates the production of group work, can be applied and is widely understood (Anderson 2007). Wiki is a preservation-friendly application that provides a history of postings to allow reversions to earlier versions of postings, as well as indications of contributors. Maness (2006) describes wikis as study group rooms in a digital library. Users create content, share information, and ask and answer questions. Librarians can also be involved in the communication. Moreover, with a long-term record of transaction history, future library patrons can retrieve information from the wiki as a reference service.

\section{- Tagging}

The main idea of tagging is to create keywords for certain objects. Although it is not considered part of a formal classification system, tags help users find resources with similar topics. Existing social tagging systems such as Delicious and LibraryThing offer easier methods for libraries to add tagging functionality to existing library systems (Rethlefsen 2007; Wenzler 2007). Delicious lets librarians and users provide collected web resources to other patrons with tags for specific topics or timely subjects. This is especially beneficial to school libraries since it serves academic librarians and students with searching needs for particular courses or assignments. Some libraries such as the Thunder Bay Public Library and the Nashville Public Library have Delicious tag clouds integrated into their website. LibraryThing, a social tagging system for publications, lets libraries include LibraryThing tags and recommendations into their OPAC systems. It helps libraries enhance user access to their collections and enables users to keep up their interest in library collections by supporting tag browsing and book recommendations. Several libraries, such as the Danbury Library, have already implemented LibraryThing into their system to let patrons find books with similar interests and suggest related tag terms.

\section{- Mash-ups}

A mash-up is a hybrid Web 2.0 application in which two or more techniques or services are combined into one new and enhanced application and service (Maness 2006). Library 2.0 is a mash-up application of the traditional library system and Web 2.0 functionalities. The combination of traditional library and new technologies creates a synergy to improve library services. A service that saves users work logs to load them when they come back can be an example of mash-up usage in Library 2.0. With these personalized services, users can search their own library transaction history including tags, social networking, conversations, posts, etc, whenever necessary (Maness 2006). LibraryThing provides applications and widgets for users' blogs or mobile devices. Users of LibraryThing can search for information in 
LibraryThing or add information to LibraryThing anywhere, e.g. in a bookstore. Such mash-ups help users participate more actively and access to the information easily at necessary time and place. Another good example of a mash-up is AquaBrowser. Several libraries already adapted AquaBrowser for their catalogue system, e.g. Upper Hudson Library System and University of Pittsburgh Library System (ULS). AquaBrowser helps users find relevant items by tags, recommended keywords, and facets. Users can send, save, or share items by connecting to any social systems with an existing account, such as Facebook and Twitter. AquaBrowser allows users to create their collections and leave tags, ratings, and reviews in each book or collection they have stored. It helps existing library systems function as Library 2.0 by providing services for user participation for customization and communication on top of traditional library systems.

\section{- E-learning, Information Literacy, and Podcasting}

For novice library patrons, a library provides several beneficial educational methods. Secker (2008) conducted a user study to find the effectiveness of various methods to support information literacy for distance users, i.e. video materials and a training session with audio and screen capture (podcasting). The result indicated that patrons in general wanted more online support with audiovisual materials. Moreover, they preferred "face-to-face" interaction if they had a chance to be in the library physically. For long distance users, online guidebooks for users in various formats are necessary to support in- formation literacy. It is recommended to use any possible Library 2.0 components as methods of user education (Godwin and Parker 2008). Recently various libraries provide reference services in a virtual environment, e.g. having a library education session in Second Life. It is considered to be efficient as it is online, real-time, visual, and interactive.

\subsubsection{Incorporating User-Generated Content in Library 2.0}

The user's role in digital libraries is becoming more important. However, Marshall (1997) raised the question of how to make information added by users to the digital materials of greater use. Aiming for Library 2.0, involvement by public users is considered important, although the quality of the information created by them becomes an issue. As an example, the metadata generation process has been known to be a process done by professionals. Generally it is considered that novices cannot create accurate descriptions of resources. However, with the popularity of social tagging systems, there is growing interest in determining if tags can be used as a type of web resource metadata (Bischoff et al. 2008; Heymann et al. 2008; Sen et al. 2007; Syn and Spring 2009; Zubiaga et al. 2009). Social tagging is an effective method to magnify user interaction and resource collection in digital libraries. Agosti et al. (2004) argued that the digital library systems may enrich their information resources with user-created annotations. With social tagging systems, users can share and access different perspectives of resources. Those interactions will en- 
hance the precision of the information seeking process for users. In addition, Sen et al. (2007) and Heymann et al. (2008) indicated social tagging systems allow users to contribute metadata for new or active pages. Heymann et al. (2008) discussed that metadata generation by humans takes more time, and as a result new resources do not appear immediately; however, in social tagging systems, they appear very quickly. Although some benefits are expected, some trade-off between quality of metadata and metadata ecology is necessary. Related to concerns about tag quality, especially when used as metadata, the results from the steve.museum study (Trant 2006) showed that the terms provided by non-specialists for museum collections are positive. It demonstrated that using tags assigned by general users might help bridge the semantic gap between the professional terminology and the popular language of the museum visitor. Zubiaga et al. (2009) suggested that user-generated annotation (tags and comments) are actually more useful in classifying web pages than using only the content of a web document. Bischoff et al. (2008) also confirmed that tags, at least in music, are reliable and as good as expert-created metadata. Although tags for music resources are more structured and controlled compared to tags for other resources, Bischoff et al. still provided a possibility of using user-entered tags. Syn and Spring (2009) discussed that in academic papers user-generated tags work fairly well as author-generated keywords, and suggested filtering noise tags will improve the usefulness of tags.

Ongoing projects in the library community are putting effort into finding effective methods of using tags to benefit users in Library 2.0. The steve museum project (Trant 2006) examines how social tagging provides new ways to describe and access museum collections that supplement existing museum documentation. With social tags gathered from their system, the steve project expects to have information that makes sense to general viewers and thereby reduces the semantic gap between professionals and the general public. Another social tagging project from the library community is the Library of Congress Photos on Flickr project. The goals of this project are to share photographs from the Library's collection, to gain a better understanding of how social tagging and community input could benefit both the Library and users of the collections, and to gain experience participating with the Web community interested in the kinds of materials in the Library's collections. They anticipate being able to learn about the ability of users to participate in the process of making constructive use of tags. The report of this pilot project revealed that users participate very actively in tagging; as a result, the tagged images were ranked high in the search results (Springer et al. 2008).

These projects hinted at the potential of collecting user-provided information and motivating users' participation. Less research has been done on how user-created information can be used in beneficial ways. Related to social tags, there are efforts to use social tags in indices for better search results, and to relate or overlap social tags with controlled vocabularies to help organize information. From previous research, it was found that there is little overlap 
among tags, automated indexing, and controlled vocabularies (Lin et al. 2006). On the other hand, Syn and Spring (2009) have shown the relatively good potential of social tags compared with controlled vocabularies. Further analysis was made by $\mathrm{Yi}$ and Chan (2009) to link folksonomy to Library of Congress Subject Headings (LCSH). They suggested further processing of compound terms would provide better structure of social tags and provide better links to LCSH. Although concrete methods have not been suggested from research yet, the potential of user involvement in improving Library 2.0 seems to be positive from previous observations and research. The important focus for future Library 2.0 development would be not only promoting users to participate but to serve back using information provided by users. To achieve this goal, it is important to understand how the roles of users and librarians have changed in Library 2.0, and then adjust the services provided by Librarian 2.0 accordingly.

\subsection{Librarian 2.0}

It is emphasized that Web 2.0 technologies can replace old library services in Library 2.0 (Maness 2006; Abram 2006, Stephens and Collins 2007) (Table 1). Yet, it is often neglected to designate who can be the major players in the process of the services. The significant characteristic of Library 2.0 often highlighted is to let users participate in library services. Although users' roles in Library 2.0 have remarkably increased, accordingly the roles of Librarian 2.0 became even more important to support user involvement. Table 1 indicates the major role players for services provided by digital libraries. As shown in Table 1, it is obvious that the responsibilities of librarians in Library 2.0 are still very important since Library 2.0 is still expected to provide supporting services such as reference services, educational services, and organizational services.

Figure 3 and 4 represent how the roles and relationships among librarians and users have changed with the shift to Library 2.0. Similar to a physical library, in a traditional digital library the roles of librarian and users are clearly divided as information provider and information consumer (Figure 3). There was no interaction between librarians and users to share the roles. On the other hand, in Library 2.0, users

$\langle$ Table 1〉 Replacement of Traditional Library Supporting Methods

\begin{tabular}{l|l|l}
\hline \multicolumn{1}{c|}{ Traditional Digital Library } & \multicolumn{1}{|c}{ Replacement in Library 2.0 } & Major Role Players in Library2.0 \\
\hline Email reference & Chatting reference, Instant Messaging & Librarians \\
\hline Text-based tutorials & Audiovisual based tutorials & Librarians \\
\hline Mailing lists/ ListServ & Blogs, wikis, RSS feeds, Calendar & Librarians \\
\hline Controlled classification schemes & $\begin{array}{l}\text { Tagging coupled with controlled } \\
\text { schemes }\end{array}$ & Librarians and Users \\
\hline Open Public Access Catalog & Customizable interface & Librarians and Users \\
\hline $\begin{array}{l}\text { Catalog of largely reliable print and } \\
\text { electronic holdings }\end{array}$ & $\begin{array}{l}\text { Catalog of reliable and suspect holdings, } \\
\text { web-pages, blogs, wikis, etc. }\end{array}$ & Librarians and Users \\
\hline
\end{tabular}


can also become information providers serving both other users and librarians (Figure 4). As users are involved in the development of the library collection, librarians are no longer just the resource provider. They need to be organizers and mediators among the users and information. To provide more flexibility for users, librarians need to understand users' needs, processes, goals, as well as their activity patterns. In Library 2.0, users have fewer limitations in adding information into the collection which may mislead other users. Namely, letting users participate in resource collection development does not mean librarians have less responsibility in collecting and organizing the collection. Rather, it is more necessary to guide users to create higher quality resources.
As a matter of fact, giving more freedom to users causes librarians in Library 2.0, namely Librarian 2.0 , to have more roles to play in managing the library system including information provider, information organizer, and information consumer.

One noticeable change in Library 2.0 is that there is bidirectional relationship between librarians and users. The librarians' role becomes more important in marking the library more attractive to patrons, and guiding patrons to contribute as information providers. Using Web 2.0 technology, much of the interaction and communication can be performed in real-time. Abram (2006) emphasized the role of Librarian 2.0 is to stay wherever users need them and interact with patrons. In other words, Librarian

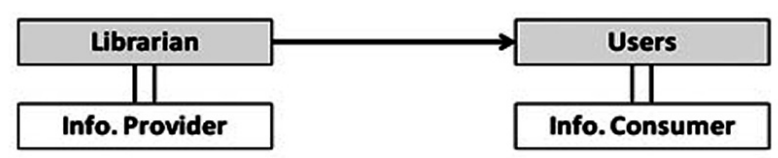

〈Figure 3〉 Role and Relationship of Stakeholders in Traditional Digital Library

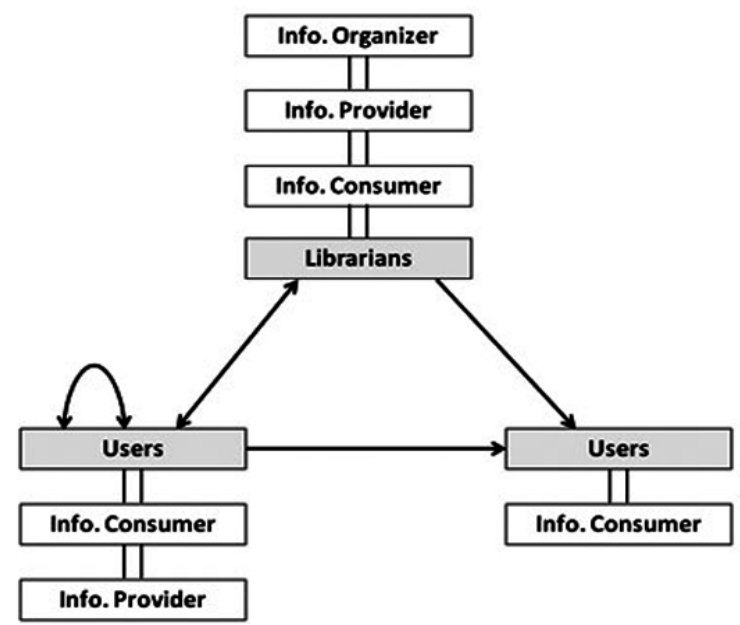

〈Figure 4〉 Role and Relationship of Stakeholders in Library 2.0 
2.0 should be available all the time for their users. Kappel et al. $(2006,225)$ explained that Web users tend to expect instant reaction when using a system - users feel unpleasant waiting longer than 3 seconds and leave the applications after 8 to 10 seconds. Similarly, library patrons may not want to wait long for their requests. Librarian 2.0 should try to respond, or at least provide the process, immediately, especially for the reference services. It is considered important as patrons waiting for answers in front of their computer cannot be aware of what librarians are doing to find solutions for their questions.

By extension, Librarian 2.0 should not limit himself or herself in using any types and formats of resources. Librarians should collect any resources, including text, image, audio, and video, and refine the information to fit to users' requests. Similarly, Librarian 2.0 is required to know Web 2.0 technologies and apply them to the library system. It makes Librarian 2.0 possible to provide properly applied library services, but also easy and well-prepared training services of library technology to users.

Another significant role of librarians in Library 2.0 is a responsibility as an educator or a trainer in both physical and digital environments. Generally, education of library patrons mainly focused on instruction for using library resources and facilities. Having more services provided in digital environments made it essential to train library patrons to be capable of dealing with digital library functionalities and technologies. Since Library 2.0 adopts various Web 2.0 technologies, the functionalities and access points might cause confusion to users. Instruction of Library
2.0 to users by Librarian 2.0 to aid in the development of their skills is also a significant contribution in upgrading users' abilities to contribute to library collection development.

\section{Discussion}

We discussed in previous chapters the development of Library 2.0 and ongoing efforts to make its services better. The shift from the traditional digital library to Library 2.0 has changed the major part of the digital library model mainly because of available technology (Web 2.0).

The transition to Library 2.0 affected the service methods that libraries provided to users. Most of all, users are allowed not only to access and manage their library accounts, but also customize personalized collections with comments, tags, and ratings. The digital library that was mainly a place to search resources became a place to socialize with other users and librarians. A digital library is no longer just an information repository, but also a playground for visitors, similar to a web portal that provides central access to any possible services of interest to users. We need to promote patrons' contributions to the library by creating, distributing, and sharing resources and information. Everyday users create and organize a number of resources, and then libraries need to provide repository and preservation services. Since there are various Web 2.0 components useful to a digital library, lots of services started to provide more focus and support to users; that is 1) the service is more real-time; 
2) the service is more social; 3) the service is more personal; 4) the service is in more media formats; and 5) the service is more interactive.

One of the major challenges in Library 2.0 is related to the increase of the patrons' role. Maness (2006) argues that Library 2.0 is not only about searching and accessing information, but finding and sharing as well. Users create content to share with other users and librarians. It can be user-generated documents or publications, but it also can be comments, opinions, or even suggestions to other resources. Users individually but cooperatively find and develop their collections. Users share the contents and information by accessing social networking applications such as wikis, blogs, RSS feeds, tags, instant messages, etc. within the library. Moreover, users can preserve their activity history including storing information, annotating, blogging, etc. for future use.

By letting users be actively involved in collection development in Library 2.0, the roles of Librarian 2.0 have become important. However, there was less emphasis on understanding the changes in roles and necessity in preparing for them. In this paper, we discussed the major roles of Librarian 2.0 in conjunction with the changed roles of Library 2.0 users. The factors of Librarian 2.0's roles can be summarized as: 1) information provider, 2) information moderator, 3) educator or trainer, 4) availability, 5) technology adopter, and 6) information consumer. Librarian 2.0 must assume all the listed roles in order to improve the quality of the library collection created by users.

Further research on how librarians and users deal with Library 2.0 technologies and how effectively services are provided by Librarian 2.0 may improve user satisfaction with digital library services. In addition, it is worth expanding the research to measure precisely how well Librarian 2.0 understands the benefits of Web 2.0 techniques and their impacts on users to further educate librarians for making the most of user-created information to improve Library 2.0 services.

\section{References}

Abram, S. 2006. "Web 2.0, Library 2.0, and the Librarian 2.0: preparing for the 2.0 world." Sirsi/Dynix OneSource, 2(1).

Agosti, M., N. Ferro, I. Frommholz, and U. Thiel. 2004. "Annotations in digital libraries and collaboratories - facets, models and usage.” In Proceeding of 8th European Conference on
Research and Advanced Technology for Digital Libraries (ECDL 2004).

Anderson, P. 2007. "What is Web 2.0?: Ideas, technologies and implications for education." JISC Technology and Standards Watch.

Bischoff, K., C. S. Firan, W. Nejdl, and R. Faiu. 2008. "Can all tags be used for search?" In 
214 Journal of the Korean Society for Information Management, 27(2), 2010

Proceedings of Conference on Information and Knowledge Management (CIKM'08). Nap Valley, California, USA, October 26-30, 2008. Black, E. L. 2007. "Web 2.0 and Library 2.0: What Librarians Need to Know.” In Nancy, C. (Ed.), Library 2.0 and Beyond: Innovative Technologies and Tomorrow's Use (pp.1-14). Libraries Unlimited.

Biancu, B. 2006. "Library 2.0 meme map - version 2.0.” In Flickr. [cited 2010.5.27]. $<$ http://www.flickr.com/photos/bonaria/1132 $22147 />$

Casey, M. E. and L. C. Savastinuk. 2006. "Library 2.0 - service for the next-generation library." Library Journal.

Courtney, N. 2007. Library 2.0 and Beyond: Innovative Technologies and Tomorrow's User. Libraries Unlimited.

Danbury Library Catalogs. [cited 2010.6.4]. $<$ http://cat.danburylibrary.org/>.

Delicious. [cited 2010.6.4]. <http://delicious.com/>.

Digital Library Federation. 1998. A Working Definition of Digital Library. [cited 2010.5.27]. $<$ http://www.diglib.org/about/dldefinition.ht $\mathrm{m}>$.

Flickr. The Library of Congress' Photostream. [cited 2010.6.4]. $<$ http://www.flickr.com/photos/Library_of Congress $>$.

Gapen, D. K. 1993. “The virtual library: Knowledge, society, and the librarian.” In L. M. Saunders (Ed.), The virtual library: Visions and realities (1-14). Westport, CT: Meckler.
Godwin, P. and J. Parker. (eds). 2008. Information Literacy meets Library 2.0. London: Facet. Habib, M. 2006. Toward Academic Library 2.0: Development and Application of a Library 2.0 Methodology. Unpublished Masters Dissertation, School of Information and Library Science of the University of North Carolina at Chapel Hill.

Heymann, P., G. Koutrika, and H. Garcia-Molina. 2008. "Can social bookmarking improve web search?" In Proceedings of Web Search and Web Data Mining (WSDM'08). Palo Alto, California, USA, February 11-12, 2008.

Johnson, K., H. Trabelsi, and T. Tin. 2004. "Library support for online learners: eResources, eServi ces and the human factors." In: Theory and practice of online learning. Athabasca: Athaba sca University. [cited 2010.5.27]. $<$ http://cde.athabascau.ca/online_book/ch14. html>.

Kansas State University Libraries. Blogs and Feeds. [cited 2010.6.4]. $<$ http://ksulib.typepad.com/>.

Kantor, P. B. 1993. "The adaptive library network interface: A historical overview and interim report." Library Hi Tech, 11: 81-92.

Kappel, G., B. Proll, S. Reich, and W. Retschitzegger. 2006. Web Engineering. ( $1^{\text {st }}$ ed.). Hoboken, NJ: Wiley \& Sons.

King, G., H. T. Kung, B. Grosz, S. Verba, D. Flecker, and B. Kahin. 1994. "The Harvard self-enriching library facilities (SELF) Project. In Proceedings of Digital Libraries '94 (DL '94), 
Texas.

Koenig, M. E. D. 1990. "Linking library users: a culture change in librarianship." American Libraries, 21: 844-849.

Kuchi, T., L. B. Mullen, and S. Tama-Bartels. 2004. "Librarians without borders: reaching out to students at a campus center." Reference \& User Services Quarterly, 43(4): 310-317.

Lin, X., J. C. Beaudoin, and K. Desai. 2006. "Exploring chracteristics of social classification." In Proceedings of the $17^{\text {th }}$ ASIS\&T SIG/CR Classification Research Workshop. November 4, 2006, Austin, TX.

Levy, D. and C. C. Marshall. 1995. "Going digital: A look at assumptions underlying digital libraries." Communications of the ACM, 38(4): 77-84.

LibraryThing for Library. [cited 2010.6.4]. $<$ http://www.librarything.com/forlibraries>.

LibraryThing. Tools. [cited 2010.6.4]. $<$ http://www.librarything.com/tools $>$.

LibraryThing. [cited 2010.6.4]. $<$ http://www.librarything.com/>.

Maness, J. 2006. "Library 2.0 Theory: Web 2.0 and Its Implications for Libraries." Webology, 3(2), Article25

Marshall, C. 1997. “Annotation: from paper books to the digital library." In Proceedings of the ACM Digital Libraries '97 Conference, Philadelphia, PA, 131-140.

Mason, J., S. Mitchell, M. Mooney, L. Reasoner, and C. Rodriguez. 2000. "INFOMINE: Promising directions in virtual library development."
First Monday, 5(6).

Nashville Public Library. Teen Web. [cited 2010.6.4]. $<\mathrm{http}$ :/www.library.nashville.org/teens/teen web.asp $>$.

O’Reilly’s Radar. 2005. “Web 2.0: Compact Definition?" [cited 2010.5.27]. $<$ http://radar.oreilly.com/2005/10/web-20-co mpact-definition.html $>$.

Renda, M. E. and U. Straccia. 2005. “A personalized collaborative digital library environment: A model and an application." Information Processing and Management, 41: 5-21.

Rethlefsen, M. L. 2007. “Tags Help Make Libraries Del.icio.us: Social bookmarking and tagging boost participation.” Library Journal. [cited 2010.5.27]. $<$ http://www.libraryjournal.com/article/CA6 476403.html>.

Secker, J. 2008. "The adventures of LASSIE: Libraries, distance learners and social software." Serials, 21(2): 112-115.

Second Life. [cited 2010.6.4]. $<$ http://secondlife.com/>.

Sen, S., F. M. Harper, A. LaPitz, and J. Riedl. 2007. "The quest for quality tags." In Proceedings of Conference on Supporting Group Work (GROUP'07). Sanibel Island, Florida, USA, November 4-7, 2007: 361-370.

Springer, M., B. Dulabahn, P. Michel, B. Natanson, D. Reser, D. Woodward, and H. Zinkham. 2008. For the Common Good: The Library of Congress Flickr Pilot Project. Library of Congress. [cited 2010.5.27]. 
216 Journal of the Korean Society for Information Management, 27(2), 2010

$<\mathrm{http}: / /$ www.loc.gov/rr/print/flickr_pilot.html>. Stephens, K. and M. Collins. 2007. "Web 2.0, Library 2.0, and the hyperlinked library." Electronic Journal Forum. 253-256.

Steve Museum Project. [cited 2010.6.4]. $<\mathrm{http}: / /$ www.steve.museum/>.

Syn, S. Y. and M. B. Spring. 2009. Tags as keywords - comparison of the relative quality of tags and keywords. In Proceedings of ASIS\&T 2009 Annual Meeting. Vancouver, BC, Canada, November 6-11, 2009.

Thunder Bay Public Library. Internet Links. [cited 2010.6.4].

$<$ http://www.tbpl.ca/internal.asp?id=283\&ci $d=333>$.

Trant, J. 2006. Social classification and folksonomy in art museum: Early data from the steve.mseum tagger prototype. In Proceedings of $17^{\text {th }}$ Workshop of the American Society for Information Science and Technology Special Interest Group in Classification Research
(ASISTSIG/CR), November 4, 2006, Austin, TX, USA.

Wenzler, J. 2007. LibraryThing and the Library Catalog: Adding Collective Intelligent to the OPAC. A Workshop on Next Generation Libraries CARLNorth IT Interest Group, September 7, 2007, San Francisco, CA, USA.

University of Pittsburgh Library System. PittCat+ Beta. [cited 2010.6.4]. $<$ http://pittcatplus.pitt.edu/>.

Upper Hudson Library System. [cited 2010.6.4]. $<$ http://aquabrowser.uhls.org/>.

Yi, K. and L. M. Chan. 2009. "Linking folksonomy to Library of Congress Subject Headings: An Exploratory Study." Journal of Documentation, 65(5): 872-900.

Zubiaga, A., R. Martinez, and V. Fresno. 2009. "Getting the most out of social annotations for web page classification." In Proceedings of Document Engineering (DocEng'09). Munich, Germany, September 16-18, 2009. 